\title{
Pemanfaatan Web E-Commerce untuk Meningkatkan Strategi Pemasaran
}

\author{
Hani Atun Mumtahana ${ }^{1 *}$, Sekreningsih $\mathrm{Nita}^{1}$, Adzinta Winerawan Tito ${ }^{1}$ \\ ${ }^{1 *}$ Program Studi Teknik Informatika \\ Universitas PGRI Madiun \\ *hany_alea03@yahoo.com
}

\begin{abstract}
Abstrak
UMKM merupakan salah satu usaha mikro yang memberdayakan industri rumahan. UMKM Indonesia memiliki kontribusi sebesar 15.8\% terhadap rantai pasok produksi global di tingkat ASEAN (1). Perkembangan UMKM dari tahun ke tahun dipengaruhi dengan pemanfaatan teknologi informasi dan sistem informasi. E-commerce merupakan salah satu teknologi yang mendukung perkembangan UMKM dan perdagangan saat ini. Pengembangan aplikasi e-commerce ini dibangun dengan menggunakan model pengembangan perangkat lunak waterfall. Tahapan pengembangan dimulai dengan analisis permasalahan dan kebutuhan untuk aplikasi pemasaran, desain model proses, desain model data, pembuatan program aplikasi, implementasi aplikasi, dan evaluasi aplikasi. Penelitian ini bertujuan untuk mengetahui dampak yang dirasakan atas pemanfaatan teknologi e-commerce dalam peningkatan strategi pemasaran produksi. Teknologi e-commerce dibangun dengan mengunakan aplikasi berbasis website, sehingga para pelaku usaha dapat mempromosikan hasil usaha dengan mudah. Sasaran utama pemanfaatan teknologi e-commerce ini adalah UMKM industri kerajinan kulit di Magetan. Pengguna dari aplikasi ini adalah administrator yang mempunyai hak penuh terhadap pengolahan aplikasi, operator atau owner merupakan pemilik toko yang memiliki hak untuk memasukkan data produk, pengguna yang memiliki hak untuk memilih dan memesan produki. Hasil uji coba dan evaluasi yang dilakukan pada koperasi mahasiswa STT Dharma Iswara Madiun, menunjukkan bahwa dengan memanfaatkan teknologi e-commerce memenuhi strategi pemasaran produk yang dapat berdampak pada peningkatan pendapatan.
\end{abstract}

Kata Kunci: UMKM, teknologi e-commerce, teknologi informasi dan sistem informasi, UMKM industri kerajinan kulit, koperasi mahasiswa STTT Dharma Iswara Madiun

\section{Pendahuluan}

Perkembangan teknologi informasi saat ini merupakan suatu kebutuhan yang harus dimiliki suatu organisasi untuk meningkatkan kualitas layanan. Pemanfaatan teknologi informasi harus diimbangi dengan implementasi sistem informasi. Teknologi informasi dan sistem informasi merupakan dua bidang yang saling berdampingan dalam penyampaian informasi bagi suatu organisasi. Pemanfaatan teknologi informasi dan sistem informasi pada suatu organisasi dapat membantu organisasi untuk mencapai tujuan dengan maksimal. Hal ini terbukti dengan semakin berkembang dan mudahnya peran teknologi informasi dan sistem informasi di kalangan organisasi.

Usaha mikro berdasarkan undang-undang nomor 20 tahun 2008 tentang UMKM (Usaha Menengah Kecil dan Mikro) adalah usaha produktif milik orang perorangan dan/atau badan usaha perorangan yang memenuhi kriteria usaha mikro sebagaimana diatur dalam undang-undang.

Pada penelitian [1] menguraikan tentang penerapan e-commerce untuk pengembangan produksi UKM di Kabupaten Semarang sangat berpeluang besar. Sampel penelitian pada 30 UKM yang ada di Kabupaten Semarang menunjukkan nilai skor 3,50 untuk persepsi pengguna terhadap manfaat e-commerce. Namun, persepsi pengguna terhadap kendala terhadap e-commerce juga sangat tinggi, yaitu skor rata-rata 3,48. Kendala tersebut muncul karena para pelaku bisnis UKM belum dapat sepenuhnya menggantikan cara tradisional dengan memanfaatkan teknologi informasi dalam melakukan transaksi.

E-commerce merupakan teknologi yang menjadi kebutuhan mendasar setiap organisasi yang bergerak di bidang perdagangan. E-commerce merupakan cara bagi konsumen untuk dapat membeli barang yang diinginkan dengan memanfaatkan teknologi internet [2]. Pemanfaatan teknologi e-commerce dapat dirasakan oleh konsumen (business to consumer) maupun oleh pelaku bisnis (business to business).

Pemanfaatan teknologi e-commerce oleh para pelaku bisnis dapat memberikan nilai positif maupun nilai negatif. Hasil penelitian [3] menjelaskan bahwa penelitian terhadap variabel perspektif risiko dan kepercayaan pelanggan terhadap e-commerce menunjukkan adanya proses saling mempengaruhi antara dua variabel tersebut. 
Hal ini ditunjukkan dengan variabel persepsi konsumen terhadap risiko yang ditimbulkan e-commerce cukup tinggi. Sedangkan kepercayaan konsumen terhadap e-commerce cenderung rendah. Salah satu faktor pengaruh tersebut adalah masih bergantungnya cara pemasaran tradisional.

Perkembangan UMKM di Magetan yang sudah banyak dikenal adalah kerajinan industri kulit. Kerajinan yang berlokasi di Jalan Sawo Kabupaten Magetan ini sudah banyak menarik minat wisatawan domestik dan mancanegara. Pertumbuhan pengrajin kulit di Magetan mulai tahun 1960 hingga saat ini terus mengalami pertumbuhan yang signifikan. Sampai saat ini sudah terdapat 36 UKM yang menghasilkan kerajinan kulit.

Permasalahan yang masih dirasakan oleh para pengrajin kulit di Kabupaten Magetan adalah kurangnya media yang digunakan untuk memasarkan hasil produksi mereka. Cara pemasaran tradisional masih menjadi andalan para pengrajin. Pusat perdagangan di Jalan Sawo Kabupaten Magetan merupakan salah satu lokasi yang paling banyak didatangi oleh para pelanggan. Selain menjajakan hasil kerajinan di setiap toko, para pengrajin juga mengikuti pameran yang diselenggarakan oleh daerah. Cara pemasaran yang masih bersifat tradisional ini sangat terbatas dalam penyampaian informasi hasil kerajinan kulit. Sehingga pemasaran hasil kerajinan yang sudah banyak dikenal oleh wisatawan domestik maupun mancanegara sangat kurang.

Pada penelitian [4] menghasilkan suatu strategi yang perlu digunakan untuk meningkatkan nilai pendapatan para pengrajin industri kulit di Kabupaten Magetan. Hasil penelitian menunjukkan berdasarkan hasil analisis lingkungan internal dan eksternal dengan menggunakan metode SWOT matrik dan PEST maka perlu adanya pemanfaatan teknologi informasi dan sistem informasi dalam bentuk e-commerce untuk meningkatkan kualitas pemasaran hasil produksi.

Penelitian ini akan menghasilkan sebuah aplikasi e-commerce yang dapat digunakan oleh pelaku bisnis sentra industri kulit Magetan. Pengembangan aplikasi dengan menggunakan model pengembangan perangkat lunak waterfall akan menghasilkan sebuah aplikasi yang sesuai dengan kebutuhan pengguna. Aplikasi ini dirancang dengan hak akses pengguna yaitu: administrator, pemilik toko (owner), dan konsumen. Aplikasi ini akan dibangun dengan menggunakan teknologi berbasis website sehingga setiap informasi terbaru akan mudah diterima oleh setiap pengguna.

Pada pengembangan aplikasi ini dirancang untuk sistem pemesanan dan pembelian secara online. Keamanan transaksi jual beli secara online merupakan salah satu variabel yang mempengaruhi minat konsumen akan menjadi pembahasan yang paling diperhatikan. Konsumen akan diberikan pilihan sistem pembayaran yaitu COD, sistem paypal, maupun transfer.

Berdasarkan permasalahan tersebut, penelitian ini akan mengembangakan sebuah aplikasi e-commerce sebagai salah satu strategi pemasaran untuk para pengrajin industri kulit di Kabupaten Magetan. Pengembangan aplikasi ini bertujuan untuk memudahkan para pelaku bisnis dalam memberi dan menerima informasi.

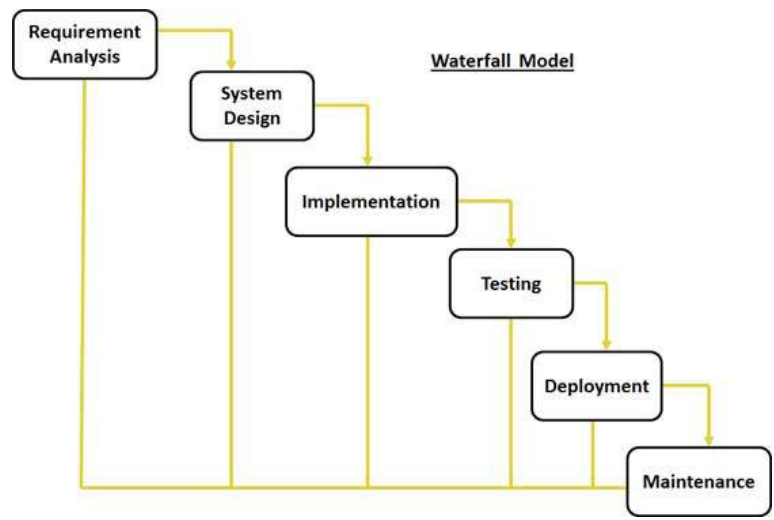

Gambar 1. Model pengembangan Waterfall [G]

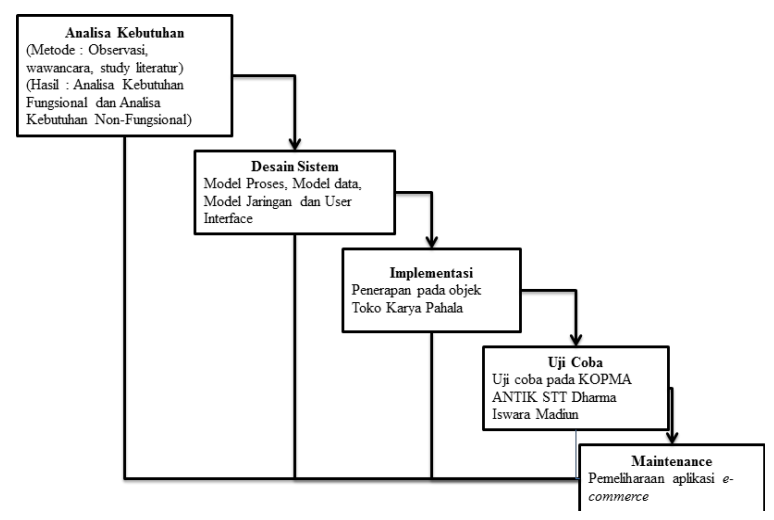

Gambar 2. Tahapan penelitian

\section{Metode}

Metodologi penelitian merupakan jabaran langkahlangkah yang akan dilakukan dalam pelaksanaan penelitian. Adapun Metodologi yang akan digunakan dalam penelitian ini adalah metodologi kualitatif. Menurut [5] metodologi penelitian kualitatif adalah suatu metodologi yang bermaksud untuk memahami fenomena tentang apa yang dialami oleh subjek penelitian. Metodologi ini merupakan metodologi yang mengesampingkan model perhitungan matematika dan statistik.

Dalam melakukan pengembangan aplikasi e-commerce digunakan model pengembangan perangkat lunak waterfall. Model pengembangan perangkat lunak waterfall adalah [6] sebuah model pengembangan perangkat lunak yang menggunakan prinsip pengembangan secara berurutan. Tahapan selanjutnya tidak akan dikerjakan jika tahapan sebelumnya belum terselesaikan. Adapun gambaran tahapan pada model pengembangan waterfall adalah sebagai berikut:

Pengembangan aplikasi e-commerce ini melalui 5 tahapan sesuai dengan model pengembangan yang digunakan. Adapun rincian kegiatan yang dilakukan pada setiap tahapan adalah sebagai berikut:

\subsection{Tahap 1: Analisis Kebutuhan}

Pada tahap ini dilakukan analisis kebutuhan untuk pengembangan aplikasi e-commerce. Metode yang digunakan dalam pengumpulan data yaitu, wawancara, pengamatan 
secara langsung, dan literatur pustaka. Pengamatan secara langsung dilakukan di sentra industri kulit Jalan Sawo Kabupaten Magetan khususnya toko Karya Pahala dan Barokah. Selain itu wawancara secara langsung dilakukan pada pemilik toko dengan kesimpulan hasil wawancara yaitu mengenai metode pemasaran yang dilakukan oleh para pengrajin yang sebagian besar masih menggunakan cara tradisional. Selain itu metode promosi juga dinaungi oleh paguyuban para pengrajin yang secara langsung berada di bawah pengawasan Dinas Pariwisata Kabupaten Magetan.

Setelah melakukan pengamatan dan wawancara secara langsung, pada tahap analisis juga dilakukan analisis kebutuhan fungsional dan kebutuhan non-fungsional pengembangan aplikasi e-commerce. Hasil analisis merupakan acuan dalam pembuatan desain model proses, model data, dan antarmuka pengguna.

\subsection{Tahap 2: Desain Sistem}

Pada tahap ini akan dibuat desain model proses, model data, dan desain antarmuka. Desain model proses digambarkan dengan United Modelling Language (UML).

\subsection{Tahap 3: Implementasi}

Pada tahap implementasi yaitu penerapan aplikasi e-commerce sesuai dengan kebutuhan dari toko Karya Pahala yang merupakan salah satu sentra terbesar di Jalan Sawo.

\subsection{Tahap 4: Uji Coba}

Pada tahap uji coba, dilakukan uji coba kegunaan aplikasi e-commerce pada koperasi mahasiswa di STT Dharma Iswara Madiun. Hasil uji coba digunakan untuk menilai tingkat kegunaan aplikasi yang telah dikembangkan sebelum ada evaluasi untuk pengembangan aplikasi lebih lanjut.

\subsection{Tahap 5: Maintenance}

Pada tahap ini dilakukan pemeliharaan aplikasi e-commerce. Langkah pemeliharaan masih dilakukan sampai dengan akhir tahun 2016.

Pada proses pengembangan belum dilakukan tahapan implementasi pada objek penelitian. Hal ini dikarenakan tahap pengembangan hasil penelitian yang masih perlu adanya penyempurnaan. Hasil akhir penerapan aplikasi e-commerce pada Kopma Antik ST'T Dharma Iswara Madiun menyatakan perlu adanya evaluasi lebih lanjut terhadap aplikasi yang akan dikembangkan pada sentra industri kulit Kabupaten Magetan.

\section{Hasil}

Pada penelitian ini menghasilkan sebuah rancang bangun aplikasi e-commerce untuk pemasaran produksi industri kulitdi Kabupaten Magetan. Modelpengembangan yang digunakan pada penelitian ini adalah model waterfall yang merupakan adopsi dari siklus hidup pengembangan perangkat lunak yang dimulai dari tahap analisis data dan kebutuhan sistem, desain sistem, pembuatan perangkat lunak, dan pengujian sistem.

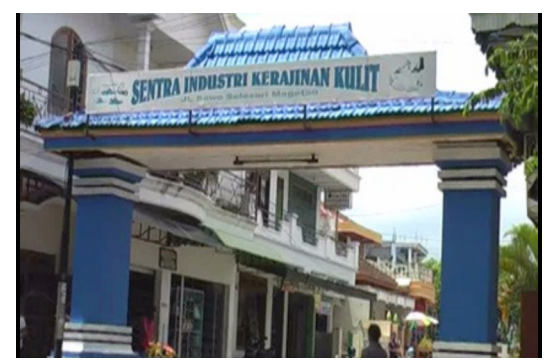

Gambar 3. Gapura Sentra Industri Kulit Magetan

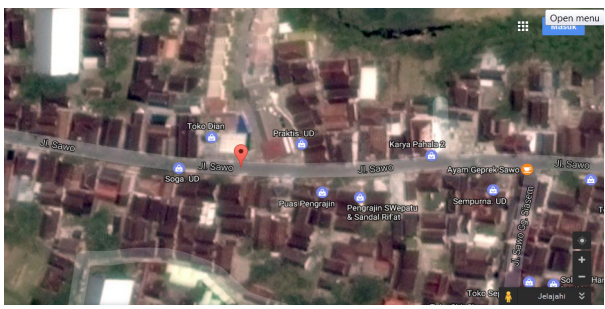

Gambar 4. Lokasi Sentra Industri Kulit Magetan

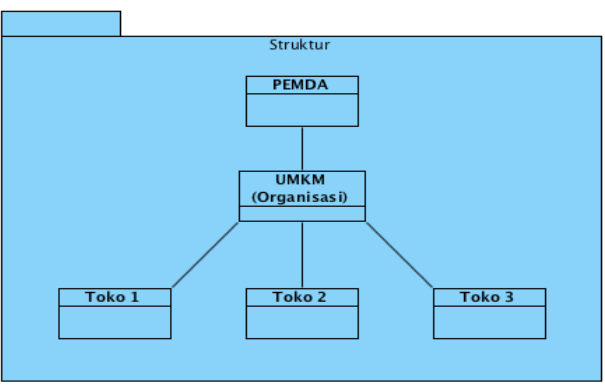

Gambar 5. Struktur Organisasi UMKM

Hasil dari penelitian yang merupakan sebuah teknologi terapan yang akan dipergunakan sebagai media promosi hasil industri kulit di Kabupaten Magetan, sehingga dapat memperluas pasar promosi yang sampai dengan saat ini telah merambah ke pasar nasional dan pasar internasional. Kelebihan dari aplikasi e-commerce ini terletak pada sistem pembayaran yang sudah menerapkan teknologi paypal. Pemilihan teknologi paypal sebagai salah satu sistem pembayaran dikarenakan sudah hampir 30\% pemasaran hasil industri kulit terjadi di pasar internasional. Pada hasil penelitian yang dilakukan mulai bulan Februari 2016 sampai dengan Desember 2016 akan dijelaskan secara rinci. Adapun hasil tersebut adalah sebagai berikut:

\subsection{Analisis Sistem Lama}

Produksi kerajinan kulit Magetan memiliki tiga lokasi di antaranya, sentra satu di Kelurahan Selosari, sentra dua di Desa Kauman, dan sentra tiga di Desa Mojopurno Kabupaten Magetan. Sentra satu tepatnya berlokasi di Jalan Sawo merupakan wilayah yang paling terkenal, karena merupakan daerah strategis dan dilalui banyak wisatawan menuju telaga Sarangan.

Kerajinan kulit ini merupakan implementasi dari kegiatan penyamakan kulit yang merupakan kebudayaan Kabupaten Magetan. Kerajinan kulit yang telah dirintis sejak tahun 1960 hingga saat ini telah menghasilkan banyak produk. Produk yang paling terkenal yaitu alas kaki (sandal dan sepatu), tetapi ada beberapa kerajinan lain yang dihasilkan antara lain, ikat pinggang, tas, jaket, aksesori. 
Tabel 1. Analisis PIECES

\begin{tabular}{|c|c|}
\hline Analisis PIECES & Sistem yang Sedang Berjalan \\
\hline $\begin{array}{c}\text { Kinerja } \\
\text { (performance) }\end{array}$ & $\begin{array}{l}\text { Sangat sulit melakukan pengecekan } \\
\text { data produk yang ada dengan produk } \\
\text { yang telah terjual karena media } \\
\text { penyimpanannya melalui kertas. }\end{array}$ \\
\hline $\begin{array}{c}\text { Informasi } \\
\text { (information) }\end{array}$ & $\begin{array}{l}\text { Promosi yang dilakukan oleh UKM } \\
\text { masih kurang sehingga masih banyak } \\
\text { masyarakat yang tidak mengenal } \\
\text { industri kulit Magetan. }\end{array}$ \\
\hline $\begin{array}{l}\text { Analisis ekonomi } \\
\quad(\text { economic })\end{array}$ & $\begin{array}{c}\text { Biaya yang tinggi untuk memasang } \\
\text { iklan di media cetak, elektronik, dan } \\
\text { percetakan brosur. }\end{array}$ \\
\hline $\begin{array}{c}\text { Keamanan atau } \\
\text { control (security or } \\
\text { control) }\end{array}$ & $\begin{array}{l}\text { Tidak adanya perbedaan antara } \\
\text { user biasa (pengunjung) dengan user } \\
\text { anggota (pelanggan). }\end{array}$ \\
\hline Efisiensi (efficiency) & $\begin{array}{l}\text { Karyawan harus mencatat data yang } \\
\text { memesan produk via telepon dan } \\
\text { sms, sehingga memakan waktu dalam } \\
\text { proses pencatatan transaksi. }\end{array}$ \\
\hline Layanan (service) & $\begin{array}{c}\text { Proses pemesanan tidak tepat guna } \\
\text { karena pelanggan harus datang } \\
\text { langsung ke Magetan. }\end{array}$ \\
\hline
\end{tabular}

Sistem yang telah bekerja sekarang ini dilakukan dengan cara manual atau kegiatan transaksi pemesanan dan penjualan yaitu melalui telepon atau datang langsung. Saat memesan produk maka karyawan akan meminta pembayaran secara DP (down payment) sebagai tanda jadi produksi dan membuat surat faktur pemesanan yang nantinya akan dikirim ke bagian produksi. Selanjutnya karyawan mencatat dan mengecek transaksi. Bagian produksi membuat produk yang diinginkan pelanggan. Setelah jadi, pelanggan bisa mengambil sendiri produk pesanannya tersebut dengan datang langsung ke UKM.

Sistem yang telah berjalan memiliki beberapa kelemahan. Untuk mengukur kualitas penyampaian informasi dilakukan analisis dengan menggunakan metode PIECES (performance, information, economic, control, efficiency, and service). Pada penelitian [7] PIECES merupakan teknik pembelajaran terbaik dan inisiatif pengembangan sebuah sistem dengan memberikan pendekatan untuk memahami dan meningkatkan perawatan sebuah sistem. Di dalam PIECES terdapat enam komponen dalam menilai kepuasan pengguna terhadap sebuah sistem informasi yaitu: (1) Performance, (2) Information, (3) Economics, (4) Control and Security, (5) Effeciency, dan (6)Service. Adapun kelemahan yang telah dianalisis dengan menggunakan metode PIECES seperti pada Tabel 1.

\subsection{Analisis Kebutuhan Fungsional}

Spesifikasi aplikasi e-commerce yang akan diusulkan adalah sebagai berikut:

a. Account, setiap user atau pengguna dapat memiliki account dan melakukan login.

b. Keranjang Belanja, fungsi yang digunakan untuk menaruh koleksi yang telah dipilih oleh penggunjung, hal ini memungkinkan pengunjung dapat membeli produk lebih dari satu.

c. Buku Tamu, digunakan untuk meninggalkan pesan, saran, atau kritik mengenai website. d. Pencarian, fungsi untuk melakukan pencarian koleksi.

e. Info Produk, informasi mengenai semua produk kerajinan kulit.

f. Metode Pembayaran, yaitu metode pembayaran yang dapat dipilih oleh pembeli, melalui kartu kredit atau tunai saat barang diantar untuk wilayah yang dapat dijangkau.

g. Pemesanan, fungsi yang disediakan bagi pelanggan yang ingin memesan produk kerajinan kulit sesuai dengan model yang diinginkan oleh pelanggan.

\subsection{Analisis Kebutuhan Non-Fungsional}

Analisis kebutuhan non-fungsional akan menjelaskan kebutuhan tentang hardware, software, dan brainware. Adapun rincian kebutuhan adalah sebagai berikut:

a. Hardware

1) Processor Core - Intel

2) Memory (RAM) - 8GB

3) Hardisk - Sandisk SSD 240GB

4) Network Speed - 1GBPs

b. Software

1) Apache - Version 2.4

2) Java

3) Unix System Operation

4) MySQL/MySQLi - Version 5.5.x

5) PHP - Version 5.4.x

6) Tomcat Version 8.5.3

7) SSL Certificates

c. Brainware

1) Administrator yang mampu mengoperasikan e-commerce

2) Owner yang mampu mengoperasikan aplikasi e-commerce

\subsection{Perancangan Use Case Diagram}

Pada tahap perancangan menggunakan model object oriented. UML (Unified Modeling Language) adalah 'bahasa' pemodelan untuk sistem atau perangkat lunak yang berparadigma 'berorientasi objek' [8]. Tujuan pemodelan (modelling) sistem adalah untuk melakukan penyederhanaan permasalahan-permasalahan yang kompleks sehingga dapat dengan mudah dipahami dan dipelajari.

Dalam UML terdapat diagram yang digunakan untuk memvisualisasikan, menspesifikasikan, membangun, dan mendokumentasikan aspek statistik dari sistem. Diagram struktur di UML terdiri atas:

a. Diagram Kelas (Class Diagram)

b. Diagram Objek (Object Diagram)

c. Diagram Komponen (Component Diagram)

d. Diagram Deployment (Deployment Diagram)

Selain diagram struktur dalam UML, terdapat diagram untuk memvisualisasikan, menspesifikasikan, membangun, dan mendokumentasikan aspek dinamis dari sistem. Diagram perilaku di UML terdiri atas:

a. Diagram Use Case (Use Case Diagram)

b. Diagram Sekuen (Sequence Diagram)

c. Diagram Kolaborasi (Collaboration Diagram)

d. Diagram Statechart (Statechart Diagram)

e. Diagram Aktivitas (Aqtivity Diagram) 


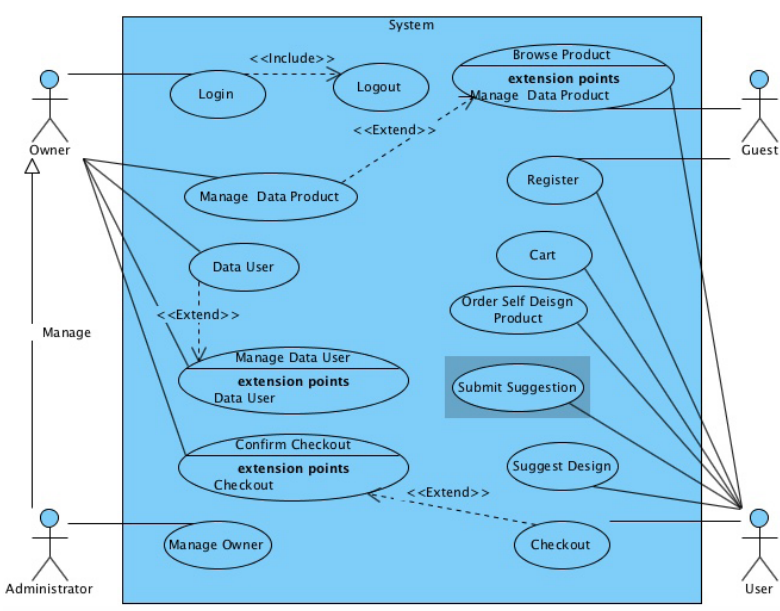

Gambar 6. Use Case Diagram

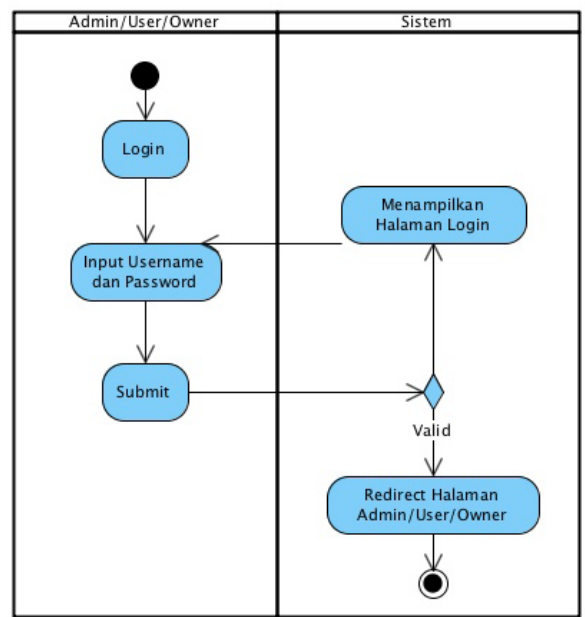

Gambar 7. Activity Diagram use case Login

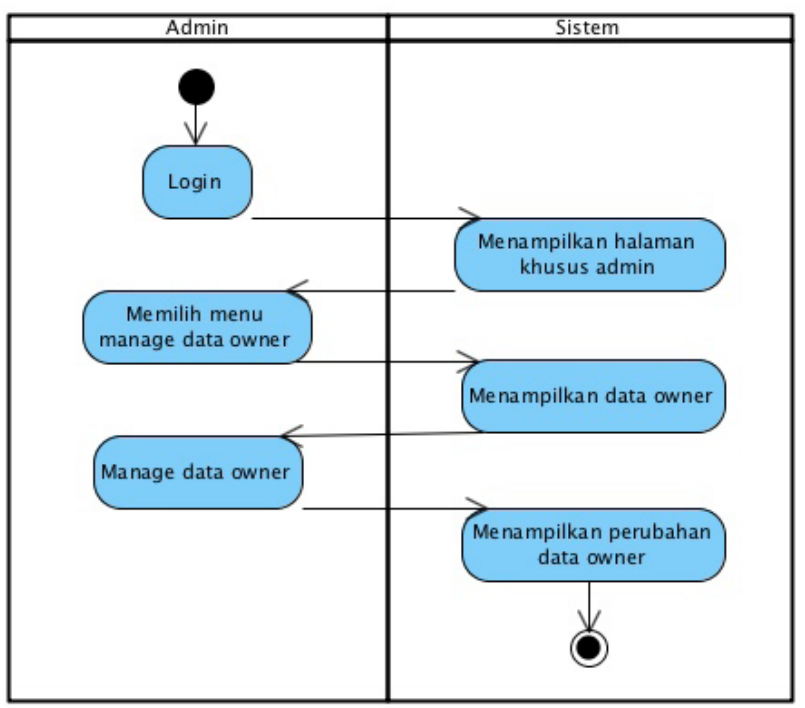

Gambar 8. Activity Diagram Manage Data Owner

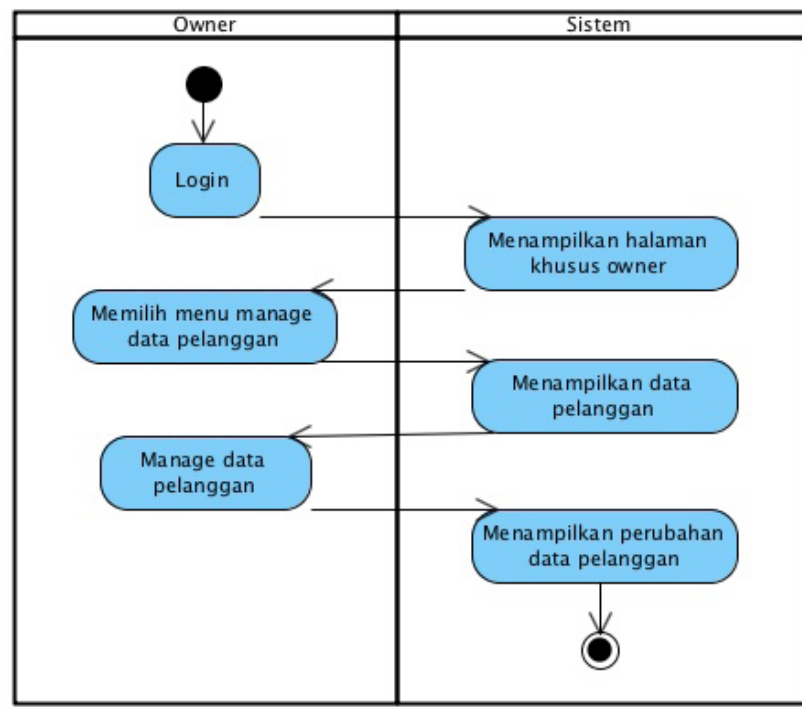

Gambar 9. Activity Diagram Manage Data Pelanggan

Pada penelitian ini akan dibangun sebuah rancangan dengan use case diagram yang akan menggambarkan perilaku setiap actor dalam mengimplementasikan aplikasi e-commerce. Menurut [9] use case diagram adalah sebuah skenario yang menggambarkan langkah-langkah yang menjelaskan interaksi antara pengguna dengan sistem untuk mencapai tujuan dari pengguna/ actor. Use case adalah interaksi antara actor eksternal dan sistem, hasil yang dapat diamati oleh actor, berorientasi pada tujuan, dideskripsikan di diagram use case dan teks. Adapun desain use case diagram pada aplikasi e-commerce seperti pada Gambar 6.

Pada Gambar 6 terdapat 4 actor dengan masingmasing memiliki kegiatan yang saling berkaitan. Adapun actor yang terlibat adalah: (1) Owner, (2) Administrator, (3) Guess, dan (4) User. Kegiatan yang dilakukan oleh setiap actor sangat berpengaruh terhadap aktivitas actor lainnya. Sehingga integrasi setiap aktivitas dan integrasi data dapat tergambar dengan jelas pada Gambar 6.

\subsection{Perancangan Activity Diagram}

Activity diagram merupakan jenis khusus dari statechart yang berfokus pada aktivitas-aktivitas, potongan-potongan dari proses yang berkorespondensi dengan metodemetode atau fungsi-fungsi anggota maupun aktivitasaktivitas yang terjadi [9]. Pada penelitian ini desain alur setiap aktivitas yang terjadi digambarkan dengan activity diagram. Gambar di bawah ini akan menjelaskan rangkaian aktivitas yang terjadi.

Gambar 7 menjelaskan activity diagram untuk login data pengguna. Hak akses login diberikan kepada administrator, owner (pemilik toko), dan pelanggan. Fungsi login diberikan untuk menjaga security data dan informasi yang disediakan.

Pada Gambar 8 menjelaskan activity diagram untuk proses kelola data owner. Pengelolaan data owner hanya dapat dilakukan oleh admin.

Pada Gambar 9 menjelaskan activity diagram untuk proses kelola data pelanggan. Pengelolaan data pelanggan dapat dilakukan oleh owner. Pelanggan yang telah melakukan registrasi pada aplikasi e-commerce dapat melakukan pemesanan dan pembelian produk. 


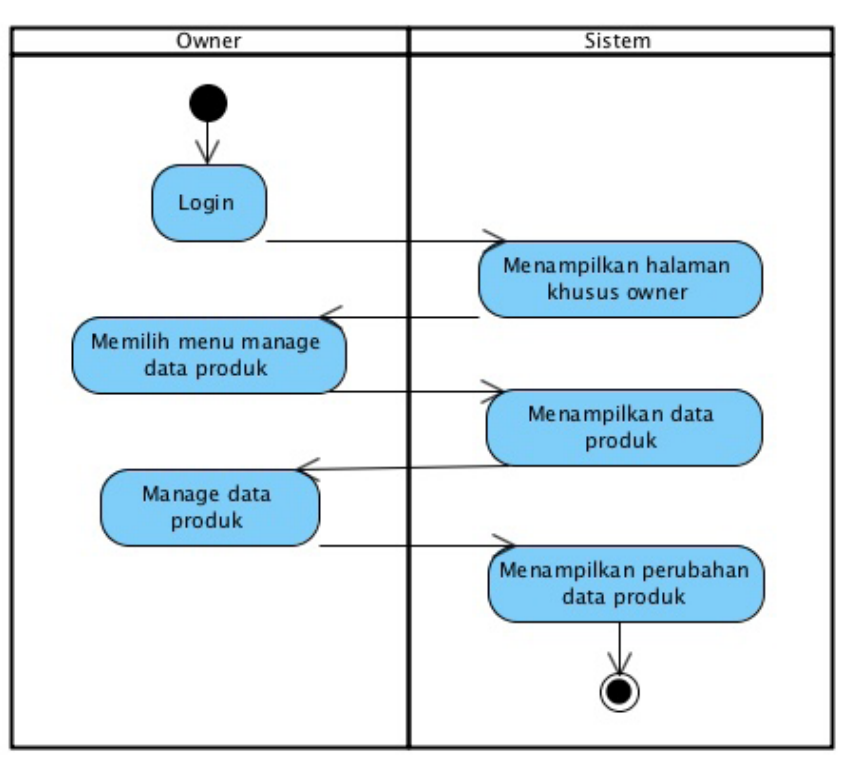

Gambar 10. Activity Diagram Use Case Manage Data Produk

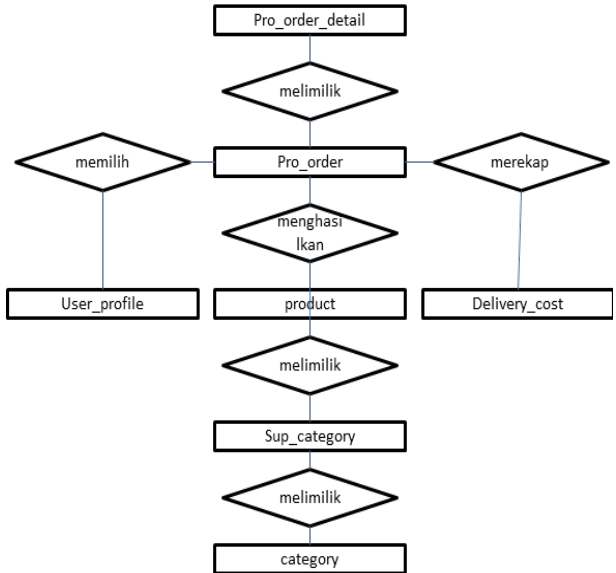

Gambar 11. ER-Diagram

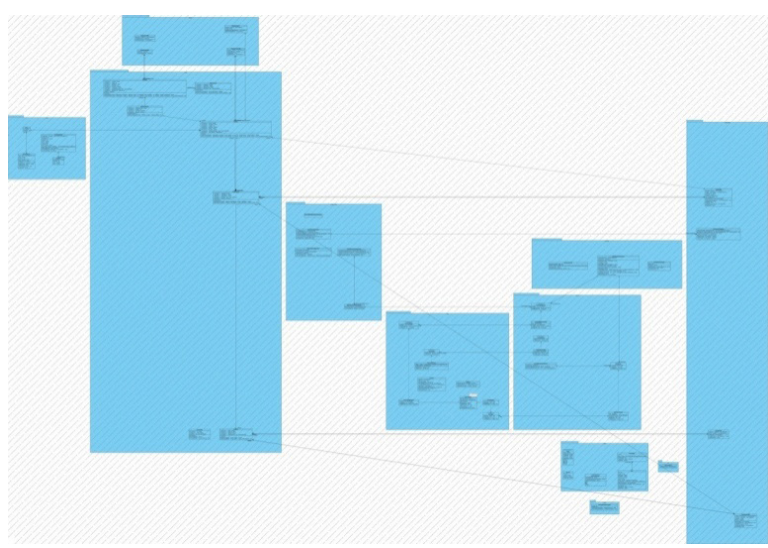

Gambar 12. Class Diagram

Gambar 10 menjelaskan activity diagram untuk proses kelola data produk. Pengelolaan data produk dapat dilakukan oleh owner. Owner (pemilik toko) dapat memasukkan data produk sesuai dengan jenis dan kategori produk yang telah dihasilkan atau dimiliki.

\subsection{Perancangan Model Data}

Pada perancangan model data digambarkan dengan desain ERD yang menjelaskan relasi antarentitas yang saling berkaitan pada aplikasi e-commerce pada konteks server. Sedangkan gambaran secara menyeluruh setelah memanfaatkan teknologi paypal digambarkan dengan desain class diagram.

a. Entity Relationship Diagram (ERD)

Pada Gambar 11 terdapat desain aliran relasi antarentitas yang menggambarkan proses order dan delivery order. Terdapat 7 entitas yang menggambarkan integrasi data antarentitas.

b. Class Diagram

Pengembangan sistem informasi tidak terlepas dari integrasi data. Data yang diolah menjadi sebuah informasi yang akan disajikan pada pengguna harus dirancang sedemikian rupa. Pada Gambar 12 menjelaskan desain integrasi data dengan menggunakan class diagram.

Class diagram ini menggambarkan desain sistem yang akan dibangun dalam database. Dapat dijadikan ilustrasi skema database yaitu dengan tabel-tabel yang akan digunakan. Setiap class akan diwakili oleh tabel, atribut, class yang akan menjadi field dalam tabel.

\subsection{Struktur Tabel}

Gambar 12 terdapat class-class yang akan ditransformasikan menjadi beberapa tabel. Hasil transformasi tabel akan menghasilkan 9 tabel untuk aplikasi e-commerce. Adapun tabel-tabel tersebut adalah sebagai berikut:

a. Tabel App_User

Tabel 2. App_User

\begin{tabular}{|c|c|c|c|c|c|}
\hline No & Field & Type & Length & Extra & Key \\
\hline 1 & Id & Bigint & 20 & $\begin{array}{c}\text { Auto } \\
\text { increment }\end{array}$ & $\begin{array}{c}\text { Primary } \\
\text { Key }\end{array}$ \\
\hline 2 & Sso_id & Varchar & 30 & & Unique \\
\hline 3 & Password & Varchar & 100 & & \\
\hline 4 & $\begin{array}{l}\text { First_ } \\
\text { name }\end{array}$ & Varchar & 30 & & \\
\hline 5 & Last_name & Varchar & 30 & & \\
\hline 6 & Email & Varchar & 30 & & \\
\hline 7 & State & Varchar & 30 & & \\
\hline
\end{tabular}

b. Tabel App_User_profile

Tabel 3. App_User_Profile

\begin{tabular}{cccccc}
\hline No & Field & Type & Length & Extra & Key \\
\hline 1 & User_id & Bigint & 20 & $\begin{array}{c}\text { Auto } \\
\text { increment }\end{array}$ & $\begin{array}{c}\text { Primary } \\
\text { Key } \\
\text { Primary } \\
\text { Key }\end{array}$ \\
\hline
\end{tabular}

c. Tabel Category

Tabel 4. Category

\begin{tabular}{cccccc}
\hline No & Field & Type & Length & Extra & Key \\
\hline 1 & Cat_id & Int & 10 & Auto & Primary \\
& unsigned & & increment & Key \\
2 & Cat_name & Varchar & 45 & & \\
3 & Cat_desc & Varchar & 200 & & \\
\hline
\end{tabular}


d. Tabel Delivery Cost

Tabel 5. Delivery_Cost

\begin{tabular}{cccccc}
\hline No & Field & Type & Length & Extra & Key \\
\hline 1 & $\begin{array}{c}\text { Delivery_ } \\
\text { id }\end{array}$ & $\begin{array}{c}\text { Int } \\
\text { unsigned }\end{array}$ & 10 & $\begin{array}{c}\text { Auto } \\
\text { increment }\end{array}$ & Primary \\
Key \\
2 & $\begin{array}{c}\text { Zone_ } \\
\text { name }\end{array}$ & Varchar & 45 & & \\
3 & $\begin{array}{c}\text { Delivery_- } \\
\text { cost }\end{array}$ & double & & & \\
\hline
\end{tabular}

e. Tabel Produk

Tabel 6. Produk

\begin{tabular}{cccccc}
\hline No & Field & Type & Length & Extra & Key \\
\hline 1 & Pro_id & $\begin{array}{c}\text { Int } \\
\text { unsigned }\end{array}$ & 10 & $\begin{array}{c}\text { Auto } \\
\text { increment }\end{array}$ & $\begin{array}{c}\text { Primary } \\
\text { Key } \\
\text { Foreign } \\
\text { Key }\end{array}$ \\
2 & Sub_cat_id & $\begin{array}{c}\text { Int } \\
\text { unsigned }\end{array}$ & 10 & & \\
3 & Pro_name & $\begin{array}{c}\text { Varchar } \\
\text { Int }\end{array}$ & 45 & & \\
4 & Pro_qty & $\begin{array}{c}\text { unsigned } \\
\text { double }\end{array}$ & 10 & & \\
5 & Pro_price & Varchar & 200 & & \\
6 & Pro_url & Varchar & 200 & & \\
7 & Pro_desc & Varchar & & &
\end{tabular}

f. Tabel Pro_Order

Tabel 7. Pro_Order

\begin{tabular}{|c|c|c|c|c|c|}
\hline No & Field & Type & Length & Extra & Key \\
\hline 1 & Order_id & $\begin{array}{c}\text { Int } \\
\text { unsigned }\end{array}$ & 10 & $\begin{array}{c}\text { Auto } \\
\text { increment }\end{array}$ & $\begin{array}{c}\text { Primary } \\
\text { Key }\end{array}$ \\
\hline 2 & Pro_id & $\begin{array}{c}\text { Int } \\
\text { unsigned }\end{array}$ & 10 & & \\
\hline 3 & Id & Bigint & 20 & & $\begin{array}{c}\text { Foreign } \\
\text { Key }\end{array}$ \\
\hline 4 & Order_date & Date & & & \\
\hline 5 & Order_qty & $\begin{array}{c}\text { Int } \\
\text { unsigned }\end{array}$ & 10 & & \\
\hline 6 & Total_price & Double & & & \\
\hline 7 & $\begin{array}{l}\text { Order_ } \\
\text { status }\end{array}$ & Varchar & 45 & & \\
\hline 8 & Delivery_id & $\begin{array}{c}\text { Int } \\
\text { unsigned }\end{array}$ & 10 & & $\begin{array}{c}\text { Foreign } \\
\text { Key }\end{array}$ \\
\hline
\end{tabular}

g. Tabel Pro_Order_Detail

Tabel 8. Pro_Order_Detail

\begin{tabular}{cccccc}
\hline No & Field & Type & Length & Extra & Key \\
\hline 1 & Order_- & $\begin{array}{c}\text { Int } \\
\text { details_id }\end{array}$ & 10 & $\begin{array}{c}\text { Auto } \\
\text { increment }\end{array}$ & $\begin{array}{c}\text { Primary } \\
\text { Key } \\
\text { Foreign } \\
\text { Int }\end{array}$ \\
2 & Order_id & $\begin{array}{c}\text { Key } \\
\text { unsigned }\end{array}$ & 10 & & $\begin{array}{c}\text { Foreign } \\
\text { Key }\end{array}$ \\
3 & Pro_id & $\begin{array}{c}\text { Int } \\
\text { unsigned } \\
\text { Int }\end{array}$ & 10 & & \\
\hline
\end{tabular}

h. Tabel Sub_Category

\begin{tabular}{cccccc}
\multicolumn{5}{c}{ Tabel 9. Sub_Category } \\
\hline No & Field & Type & Length & Extra & Key \\
\hline 1 & Subcat_id & $\begin{array}{c}\text { Int } \\
\text { unsigned } \\
\text { Int } \\
\text { unsigned }\end{array}$ & 10 & $\begin{array}{c}\text { Auto } \\
\text { increment }\end{array}$ & $\begin{array}{c}\text { Primary } \\
\text { Key } \\
\text { Foreign } \\
\text { Key }\end{array}$ \\
3 & $\begin{array}{c}\text { Cat_id } \\
\text { Sub_cat_ } \\
\text { name } \\
\text { Sub_cat_ } \\
\text { desc }\end{array}$ & Varchar & 45 & \\
\hline
\end{tabular}

i. Tabel User_profile

Tabel 10. User_Profile

\begin{tabular}{cccccc}
\hline No & Field & Type & Length & Extra & Key \\
\hline 1 & Id & Bigint & 20 & $\begin{array}{c}\text { Auto } \\
\text { increment }\end{array}$ & $\begin{array}{c}\text { Primary } \\
\text { Key }\end{array}$ \\
2 & Type & Varchar & 20 & & Unique \\
\hline
\end{tabular}
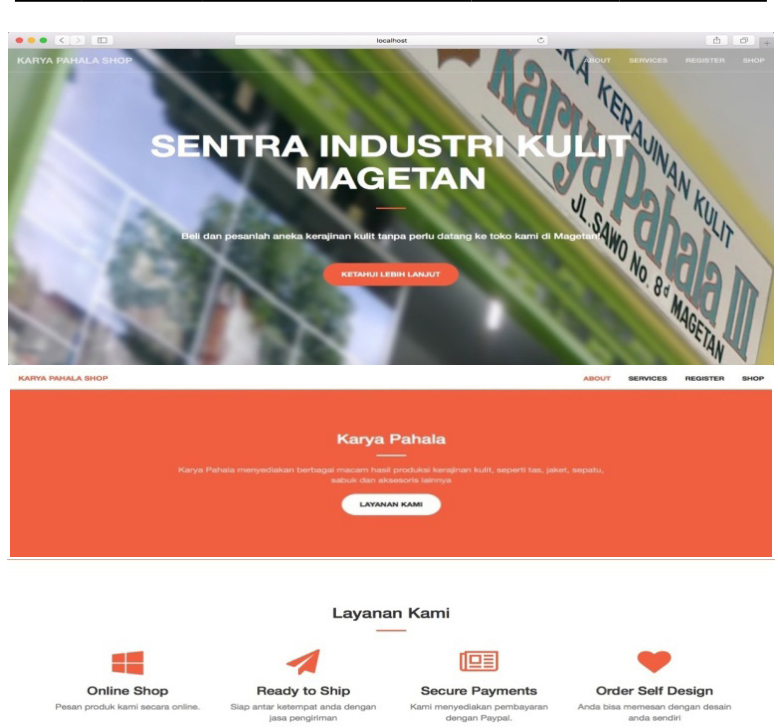

Gambar 13. Tampilan Antarmuka Home

\subsection{Implementasi Sistem}

Pada tahap implementasi aplikasi e-commerce masih dijalankan secara local. Adapun tampilan user interface adalah sebagai berikut:

Gambar 13 menjelaskan tampilan antarmuka untuk halaman utama. Pada halaman ini memberikan informasi tentang UKM yang terdapat di sentra industri kulit Magetan dan contoh produk yang dimiliki masing-masing UKM. 


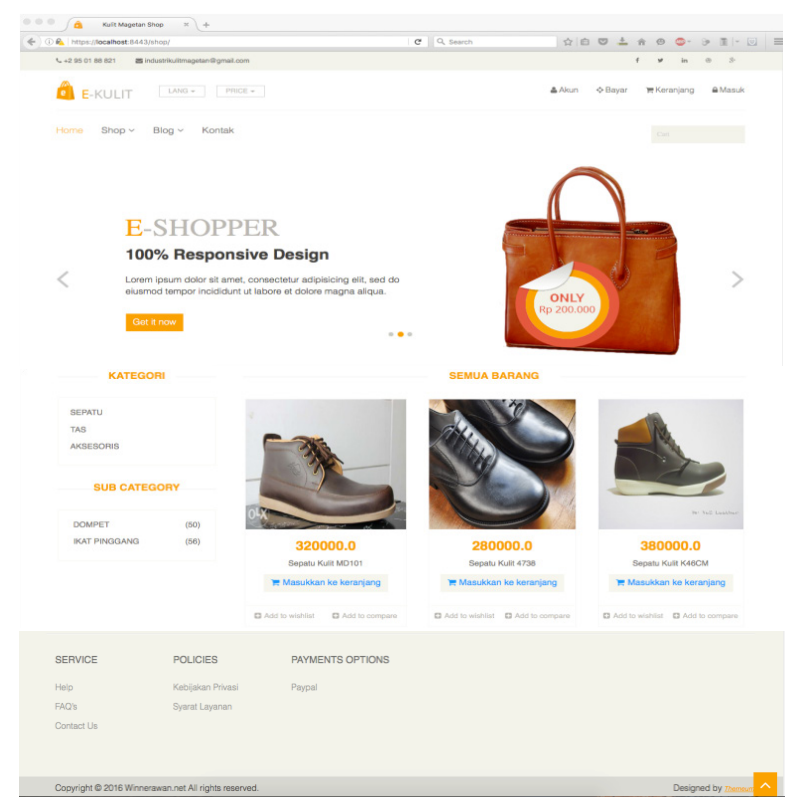

Gambar 14. Halaman Kategori

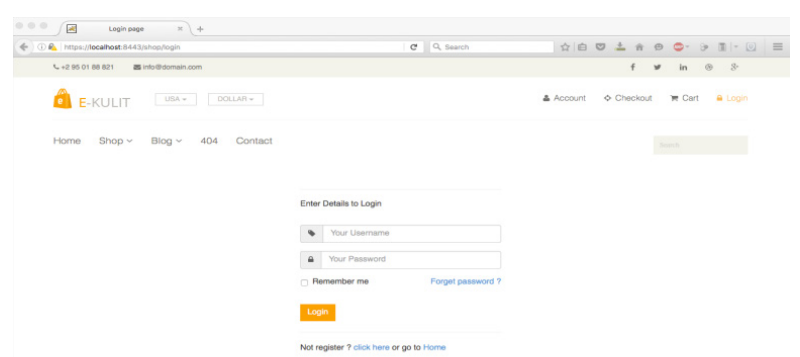

Gambar 15. Halaman Login

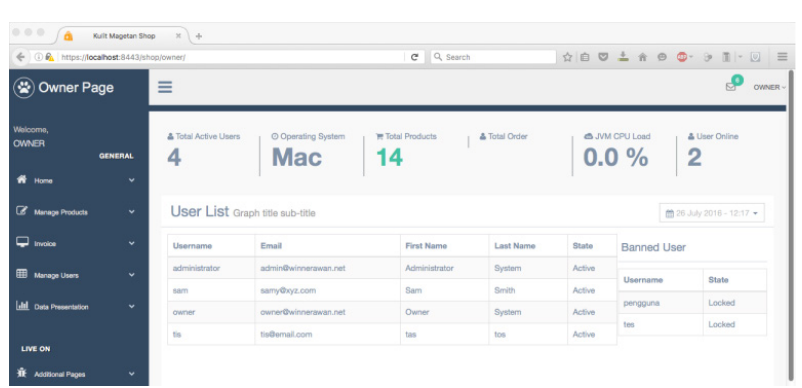

Gambar 16. Halaman Akses Owner

Gambar 14 memberikan informasi tentang katergori produk yang ada di UKM Karya Pahala (salah satu contoh UKM di Jalan Sawo). Informasi produk pada setiap katalog menjelaskan tentang kriteria produk beserta harga dan status ketersediaan produk.

Gambar 15 merupakan halaman antarmuka untuk melakukan login. Login dapat dilakukan oleh administrator, owner (pemilik toko), dan pelanggan.

Gambar 16 merupakan halaman yang hanya dapat diakses oleh owner. Pada halaman ini owner dapat melakukan penambahan informasi dan penghapusan informasi terhadap produk yang dimiliki.

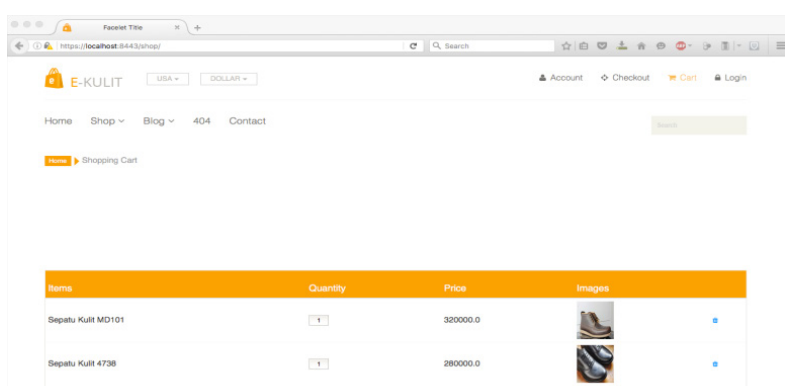

Gambar 17. Halaman Pembelian Online

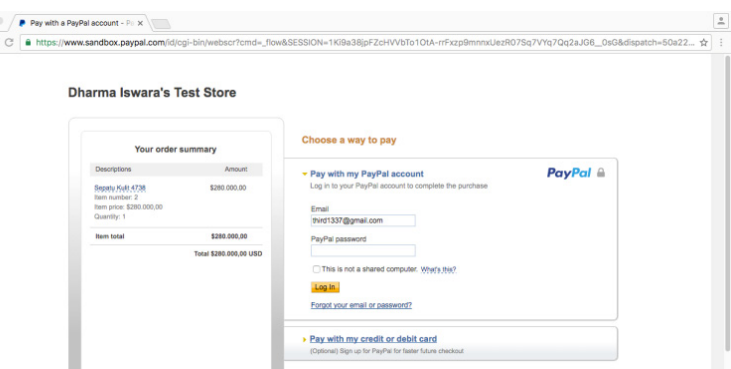

Gambar 18. Halaman Login Paypal

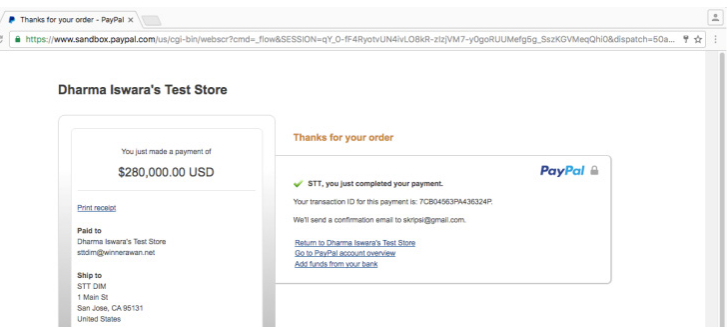

Gambar 19. Pembayaran dengan Paypal

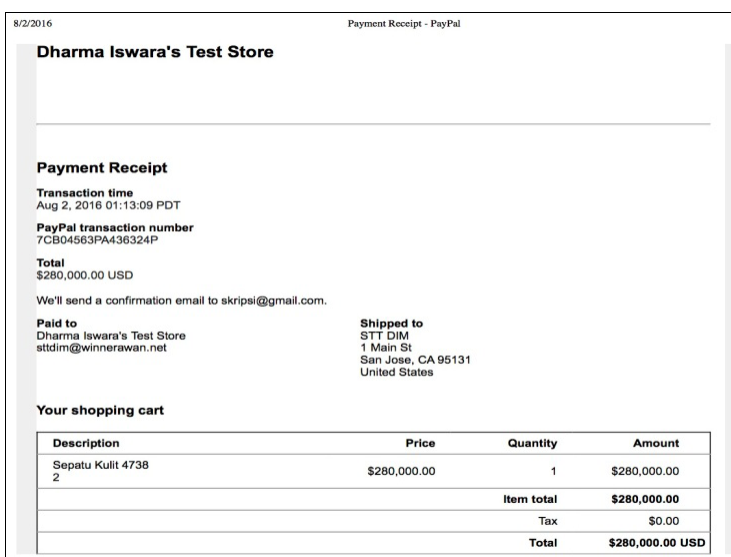

Gambar 20. Cetak Paypal

Gambar 17 memberikan informasi pembelian online yang dilakukan oleh pelanggan. Pelanggan dapat melakukan pemesanan produk yang diinginkan. Selain itu pelangan juga dapat melakukan pembelian produk yang ada.

Gambar 18 merupakan halaman untuk pelanggan yang melakukan pembelian melalui aplikasi e-commerce. Pembelian secara online dapat dilakukan pembayaran dengan cara paypal. Pada halaman paypal ini pembeli bisa me-review ulang informasi tentang pembelian barang, paypal balance, serta alamat pengiriman yang dapat diubah. 


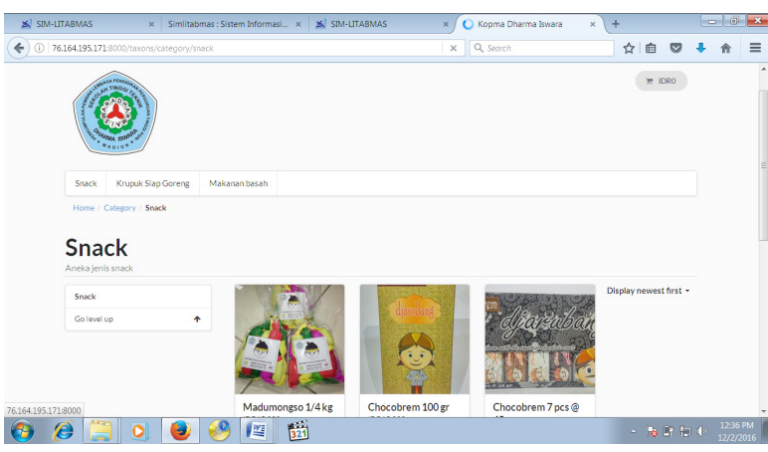

Gambar 21. Halaman utama e-commerce Kopma Antik

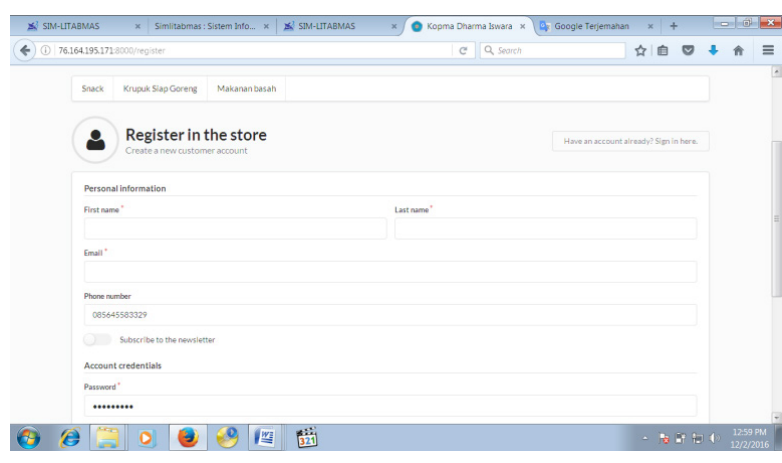

Gambar 22. Halaman Registrasi Pelanggan

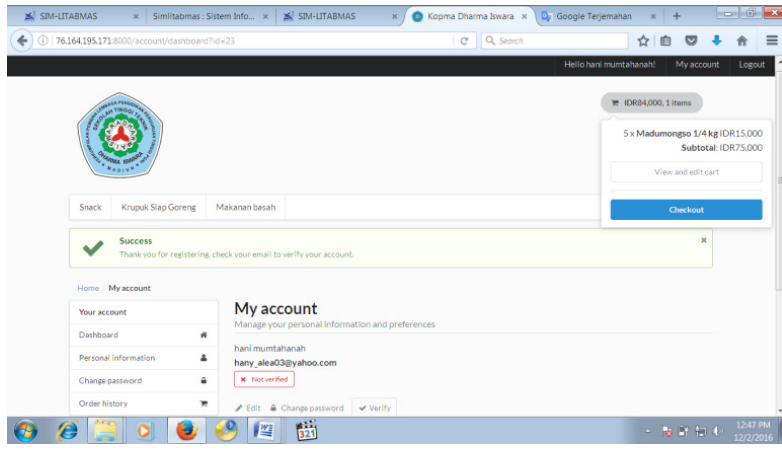

Gambar 23. Halaman Profil Pelanggan

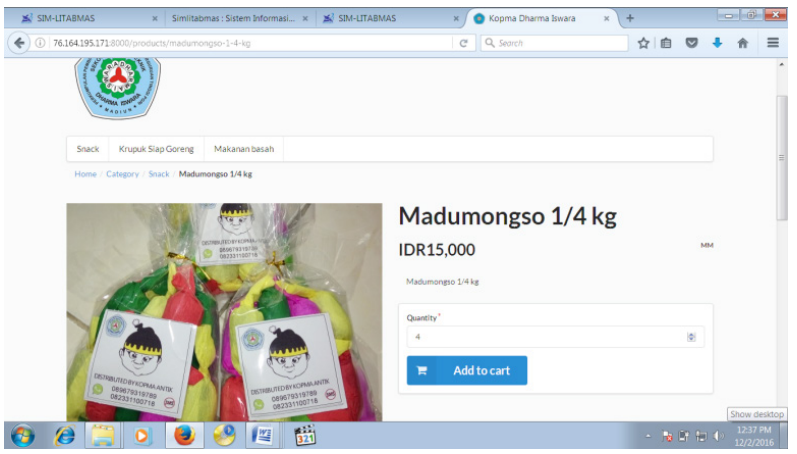

Gambar 24. Halaman Pembelian Produk

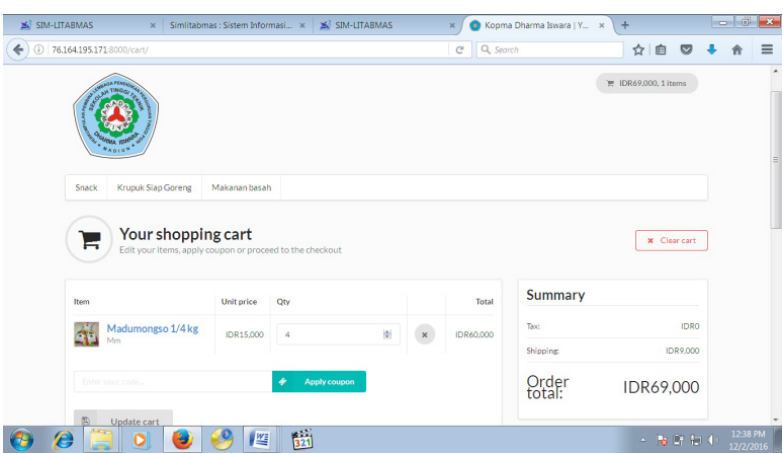

Gambar 25. Halaman Konfirmasi Pembelian

Gambar 19 menampilkan informasi total pembayaran yang harus dikeluarkan oleh pelanggan. Selain itu terdapat beberapa informasi untuk melakukan pembayaran.

Setelah melakukan transaksi, maka sistem akan menampilkan bukti transaksi untuk pelanggan. Gambar 20 merupakan tampilan dari bukti transaksi untuk pelanggan.

\subsection{Uji Coba Sistem}

Pada tahap selanjutnya adalah melakukan uji coba aplikasi e-commerce. Uji coba aplikasi bertujuan untuk melakukan penilaian terhadap tingkat kegunaan aplikasi e-commerce terhadap kebutuhan pengguna. Pengujian aplikasi dilakukan pada koperasi mahasiswa ST"T Dharma Iswara Madiun. Adapun instrumen antarmuka dalam uji coba adalah sebagai berikut:

\section{KESIMPULAN}

Pada penelitian ini menghasilkan sebuah rancang bangun sebuah aplikasi e-commerce untuk sentra industri kulit di Kabupaten Magetan. Aplikasi e-commerce ini akan menjadi salah satu penerapan teknologi sebagai media pemasaran hasil industri kulit yang ada di sentra industri kulit Kabupaten Magetan. Uji coba aplikasi pada Kopma Antik STT Dharma Iswara Madiun dilakukan untuk mengetahui tingkat kegunaan terhadap kebutuhan pengguna. Adanya aplikasi e-commerce ini mampu meningkatkan hasil pemasaran produk Kopma Antik STT sebanyak 15\%. Di dalam tahap uji coba masih belum menggunakan metode yang akan menghasilkan sebuah nilai kuantitatif dari hasil uji coba. Pada penelitian selanjutnya akan dilakukan pengujian aplikasi dengan menggunakan teori Nielsen untuk mengetahui tingkat kegunaan aplikasi e-commerce.

\section{DAFTAR PUSTAKA}

[1] Agustin, Eva M.S, "Persepsi Penggunaan Aplikasi Internet untuk Pemasaran Produk Usaha Kecil Menengah," in Seminar Nasional Aplikasi Teknologi Informasi (SNATI), Yogyakarta, 2007, pp. J-13.

[2] Haryanti, Sri. Tri Irianto, "Rancang Bangun Sistem Informasi E-Commerce Untuk Usaha Fashion Studi Kasus Omah Mode Kudus," Jurnal Speed-Sentra Penelitian Engineering dan Edukasi, vol. Vol. 3, no. 1, pp. 8-14, 2011. 
[3] Firdayanti Restika, "Persepsi Risiko Melakukan E-Commerce dengan Kepercayaan Konsumen dalam Membeli Produk Fashion Online," Journal of Social and Industrial Psychology, vol. I, no. 1, pp. 1-7, 2012.

[4] Mumtahana, Hani Atun. Sekreningsih Nita, "Analisis Optimalisasi Penggunaan Teknologi Informasi dalam peningkatan Kualitas dan Pemasaran Produksi Kulit Magetan," in Seminar Nasional Teknik dan Manajemen Industri, Malang, 2015, pp. IV-22 - IV 27.

[5] Jhon A. Zachman, The Zachman Framework For Enterprise Architecture., 2003.

[6] S Balaji and Dr. M. Sundararajan Murugaiyan, "Waterfall Vs V-Model Vs Agile : A Comparative Study On SDLC," International Journal of Information Technology and Business Management, vol. II, no. 1, pp. 26-29, June 2012.
[7] Adi Supriyatna, "Analisis dan Evaluasi Kepuasan Pengguna Sistem Informasi Perpustakaan dengan Menggunakan PIECES Framework," Jurnal Pilar Nusa Mandiri, vol. XI, no. 1, pp. 43-52, Maret 2015.

[8] Adi Nugroho, Rekayasa Perangkat Lunak Berorientasi Objek dengan Metode USDP. Yogyakarta, Indonesia: Andi Yogyakarta, 2010.

[9] Michael Yoseph Ricky, "Analisis dan Perancangan Sistem Informasi Laboratorium Rumah Sakit Kanker Dharmais dengan menggunakan Total Architecture Syntesis," Comtech, vol. I, no. 2, pp. 561-574, Desember 2010. 